\title{
Internal Cation Mobilities in the Molten Binary System $(\mathrm{Ag}, \mathrm{Tl}) \mathrm{NO}_{3}$
}

\author{
Pao-hwa Chou and Isao Okada \\ Department of Electronic Chemistry, Tokyo Institute of Technology, \\ Nagatsuta 4259, Midori-ku, Yokohama 226, Japan
}

Z. Naturforsch. 51 a, 197-199 (1996); received November 27, 1995

\begin{abstract}
Internal mobility ratios in the molten binary system $(\mathrm{Ag}, \mathrm{Tl}) \mathrm{NO}_{3}$ have been measured by Klemm's countercurrent electromigration method. In the usual way the internal cation mobilities $b$ have been calculated from these data and those available on the densities and conductivities. In the investigated region of temperature and composition $b_{\mathrm{Ag}}$ is greater than $b_{\mathrm{T} 1}$.
\end{abstract}

\section{Introduction}

Papers on the internal cation mobilities in molten $(\mathrm{Ag}, \mathrm{M}) \mathrm{MO}_{3}$ and $(\mathrm{Tl}, \mathrm{M}) \mathrm{NO}_{3}(\mathrm{M}=$ alkali metal ion), as measured by Klemm's countercurrent electromigration method, are listed in Table 1. The system $(\mathrm{Ag}, \mathrm{Tl}) \mathrm{NO}_{3}$ studied in the present paper is interesting when compared with the aforementioned systems. The melting points of the eutectic mixtures $\left(x_{\mathrm{Ag}}=0.486\right.$ and 0.515 ) are at $81^{\circ} \mathrm{C}$ [7], and also the melting points of $\mathrm{AgNO}_{3}\left(212^{\circ} \mathrm{C}\right)$ and $\mathrm{TlNO}_{3}\left(206^{\circ} \mathrm{C}\right)$ are considerably lower than those of the alkali nitrates.

Table 1. Molten binary systems (Ag, M) NO $\mathrm{NO}_{3}$ and ( $\mathrm{Tl}$, M) $\mathrm{NO}_{3}$ whose internal cation mobility ratios have so far been studied by Klemm's method.

\begin{tabular}{llllll}
\hline & $\mathrm{M}$ & & & & \\
\cline { 2 - 6 } & $\mathrm{Li}^{+}$ & $\mathrm{Na}^{+}$ & $\mathrm{K}^{+}$ & $\mathrm{Rb}^{+}$ & $\mathrm{Cs}^{+}$ \\
\hline $\mathrm{Ag}^{+}$ & {$[1]$} & {$[2]$} & {$[1]$} & {$[3]$} & {$[3]$} \\
$\mathrm{Ti}^{+}$ & {$[4]$} & {$[5]$} & {$[6]$} & {$[4]$} & {$[6]$} \\
\hline
\end{tabular}

\section{Experimental}

The chemicals $\mathrm{AgNO}_{3}$ and $\mathrm{TlNO}_{3}$ of reagent grade, made by Wako Chem. Co. Ltd. and Misawa Chem. Co. Ltd., Japan, respectively, were used without further purification. These salts were vacuum-dried at $180^{\circ} \mathrm{C}$ for $48 \mathrm{hr}$ and mixed at chosen ratios by weighing.

Reprint requests to Professor I. Okada.
For electromigrations above $220^{\circ} \mathrm{C}$, the cell was of the type described in [8]. Molten $\mathrm{NH}_{4} \mathrm{NO}_{3}$ was used as catholyte, and the large vessel in which the separation tube was set contained the eutectic mixture of ( $\mathrm{Li}, \mathrm{Na}, \mathrm{K}) \mathrm{NO}_{3}\left(30,17\right.$ and $53 \mathrm{~mol} \%$; mp.: $120^{\circ} \mathrm{C}$ [7]).

For electromigrations below $170^{\circ} \mathrm{C}$ a cell of the type shown in [9] was employed, which contained the eutectic mixture of $\left(\mathrm{Li}, \mathrm{NH}_{4}\right) \mathrm{NO}_{3} \quad(25.3$ and $74.7 \mathrm{~mol} \%$; mp.: $120^{\circ} \mathrm{C}$ [7]) in the large vessel.

A separation tube of Vycor of $4 \mathrm{~mm}$ inner diameter was filled with alumina powder $(150-180 \mu \mathrm{m})$. The temperature of the separation tube was kept constant within $\pm 2{ }^{\circ} \mathrm{C}$ by a controller. After electromigration at $90 \mathrm{~mA}$ for a few hours the separation tube was taken out, cleaned on the outside and cut into pieces of 6-7 mm length. Each fraction was dissolved in dilute nitric acid for several hours. The content of $\mathrm{Ag}$ and $\mathrm{Tl}$ atoms was determined by atomic absorption spectrophotometry and flame spectrophotometry, respectively.

The temperature was measured by an AlumelChromel thermocouple, which was located in the eutectic mixture at a distance of about $1.5 \mathrm{~cm}$ from the part of the separation tube where the initial concentration did not change. The temperature difference between the thermocouple and the inside of the separation tube was estimated according to [10] to be about $1{ }^{\circ} \mathrm{C}$.

\section{Results}

The relative difference in the internal mobilities $b_{13}$ and $b_{23}\left(1=\mathrm{Ag}, 2=\mathrm{Tl}, 3=\mathrm{NO}_{3}\right)$, defined by

$$
\varepsilon=\left(b_{13}-b_{23}\right) / b_{c},
$$


Table 2. Experimental conditions and $\varepsilon$ in the molten system $(\mathrm{Ag}, \mathrm{Tl}) \mathrm{NO}_{3} \cdot Q$ is the transported charge.

\begin{tabular}{|c|c|c|c|}
\hline$T /{ }^{\circ} \mathrm{C}$ & $x_{\mathrm{Tl}}$ & $Q / \mathrm{C}$ & $\varepsilon$ \\
\hline 120 & $\begin{array}{l}0.398 \pm 0.001 \\
0.493 \pm 0.002 \\
0.571 \pm 0.003\end{array}$ & $\begin{array}{r}982 \\
927 \\
1003\end{array}$ & $\begin{array}{l}0.266 \pm 0.008 \\
0.269 \pm 0.003 \\
0.220 \pm 0.002\end{array}$ \\
\hline 140 & $\begin{array}{l}0.391 \pm 0.002 \\
0.498 \pm 0.001 \\
0.579 \pm 0.001\end{array}$ & $\begin{array}{l}959 \\
947 \\
986\end{array}$ & $\begin{array}{l}0.332 \pm 0.004 \\
0.338 \pm 0.003 \\
0.247 \pm 0.001\end{array}$ \\
\hline 170 & $\begin{array}{l}0.278 \pm 0.004 \\
0.492 \pm 0.002 \\
0.693 \pm 0.002\end{array}$ & $\begin{array}{r}998 \\
1084 \\
921\end{array}$ & $\begin{array}{l}0.310 \pm 0.009 \\
0.319 \pm 0.004 \\
0.328 \pm 0.004\end{array}$ \\
\hline 220 & $\begin{array}{l}0.050 \pm 0.000 \\
0.105 \pm 0.001 \\
0.291 \pm 0.001 \\
0.479 \pm 0.000 \\
0.698 \pm 0.002 \\
0.919 \pm 0.003\end{array}$ & $\begin{array}{l}1030 \\
1075 \\
1040 \\
1051 \\
1046 \\
1099\end{array}$ & $\begin{array}{l}0.270 \pm 0.003 \\
0.223 \pm 0.008 \\
0.214 \pm 0.004 \\
0.283 \pm 0.003 \\
0.286 \pm 0.004 \\
0.181 \pm 0.005\end{array}$ \\
\hline 270 & $\begin{array}{l}0.046 \pm 0.001 \\
0.098 \pm 0.001 \\
0.300 \pm 0.001 \\
0.488 \pm 0.004 \\
0.691 \pm 0.002 \\
0.901 \pm 0.002\end{array}$ & $\begin{array}{l}1117 \\
1037 \\
1036 \\
1091 \\
1097 \\
1094\end{array}$ & $\begin{array}{l}0.302 \pm 0.015 \\
0.246 \pm 0.010 \\
0.254 \pm 0.004 \\
0.251 \pm 0.005 \\
0.247 \pm 0.002 \\
0.195 \pm 0.010\end{array}$ \\
\hline 320 & $\begin{array}{l}0.047 \pm 0.001 \\
0.096 \pm 0.002 \\
0.302 \pm 0.001 \\
0.496 \pm 0.002 \\
0.699 \pm 0.001 \\
0.888 \pm 0.004\end{array}$ & $\begin{array}{l}1051 \\
1046 \\
1065 \\
1011 \\
1022 \\
1020\end{array}$ & $\begin{array}{l}0.247 \pm 0.010 \\
0.258 \pm 0.014 \\
0.217 \pm 0.002 \\
0.227 \pm 0.003 \\
0.225 \pm 0.003 \\
0.095 \pm 0.006\end{array}$ \\
\hline 350 & $\begin{array}{l}0.047 \pm 0.000 \\
0.092 \pm 0.001 \\
0.300 \pm 0.000 \\
0.475 \pm 0.003 \\
0.697 \pm 0.002 \\
0.888 \pm 0.003\end{array}$ & $\begin{array}{l}1025 \\
1060 \\
1061 \\
1062 \\
1045 \\
1045\end{array}$ & $\begin{array}{l}0.238 \pm 0.007 \\
0.237 \pm 0.010 \\
0.204 \pm 0.002 \\
0.203 \pm 0.004 \\
0.208 \pm 0.004 \\
0.116 \pm 0.006\end{array}$ \\
\hline
\end{tabular}

was derived from an equation [11] which is based on the charge and material balances. Here,

$$
b_{\mathrm{c}}=x_{13} b_{13}+x_{23} b_{23}=\kappa V_{\mathrm{m}} / F,
$$

where $x_{13}$ and $x_{23}$ are the mole fractions of the salts, $\kappa$ is the conductivity, $V_{\mathrm{m}}$ the molar volume of the mixture, and $F$ the Faraday constant.

The obtained values of $\varepsilon$ are given in Table 2 together with the main experimental conditions. The internal cation mobilities $b_{13}$ and $b_{23}$ were calculated from the $\varepsilon$ values and the data [12] on the densities and conductivities. The calculated values are given in Table 3, and the corresponding isotherms are shown in Figs. $1 \mathrm{a}$ and $1 \mathrm{~b}$. Since at low temperatures the liquid range of the concentrations decreases, the region to be covered for the mobility isotherms $b$ decreased as well.
Table 3. Internal mobilities of $\mathrm{Ag}^{+}$and $\mathrm{Tl}^{+}$in the molten system $(\mathrm{Ag}, \mathrm{Tl}) \mathrm{NO}_{3}$.

\begin{tabular}{|c|c|c|c|c|c|}
\hline$T /{ }^{\circ} \mathrm{C}$ & $x_{\mathrm{Tl}}$ & $\begin{array}{l}\kappa \\
10^{2} \mathrm{~S} \\
\mathrm{~m}^{-1}\end{array}$ & $\begin{array}{l}V_{\mathrm{m}} \\
10^{-6} \mathrm{~m}^{3} \\
\mathrm{~mol}^{-1}\end{array}$ & $\begin{array}{l}b_{\mathrm{Ag}} \\
10^{-8} \mathrm{~m}^{2} \\
\mathrm{~V}^{-1} \mathrm{~s}^{-1}\end{array}$ & $\begin{array}{l}b_{\mathrm{Tl}} \\
10^{-8} \mathrm{~m}^{2} \\
\mathrm{~V}^{-1} \mathrm{~s}^{-1}\end{array}$ \\
\hline 120 & $\begin{array}{l}0.398 \\
0.493 \\
0.571\end{array}$ & $\begin{array}{l}0.1722 \\
0.1634 \\
0.1570\end{array}$ & $\begin{array}{l}45.84 \\
46.89 \\
47.75\end{array}$ & $\begin{array}{l}0.905 \pm 0.002 \\
0.900 \pm 0.001 \\
0.875 \pm 0.001\end{array}$ & $\begin{array}{l}0.687 \pm 0.004 \\
0.685 \pm 0.001 \\
0.704 \pm 0.000\end{array}$ \\
\hline 140 & $\begin{array}{l}0.391 \\
0.498 \\
0.579\end{array}$ & $\begin{array}{l}0.2457 \\
0.2312 \\
0.2213\end{array}$ & $\begin{array}{l}46.05 \\
47.24 \\
48.15\end{array}$ & $\begin{array}{l}1.325 \pm 0.002 \\
1.323 \pm 0.001 \\
1.263 \pm 0.001\end{array}$ & $\begin{array}{l}0.935 \pm 0.003 \\
0.938 \pm 0.001 \\
0.989 \pm 0.000\end{array}$ \\
\hline 170 & $\begin{array}{l}0.278 \\
0.492 \\
0.693\end{array}$ & $\begin{array}{l}0.3831 \\
0.3350 \\
0.2968\end{array}$ & $\begin{array}{l}45.21 \\
47.64 \\
49.96\end{array}$ & $\begin{array}{l}1.951 \pm 0.005 \\
1.915 \pm 0.003 \\
1.887 \pm 0.005\end{array}$ & $\begin{array}{l}1.394 \pm 0.013 \\
1.387 \pm 0.003 \\
1.383 \pm 0.002\end{array}$ \\
\hline 220 & $\begin{array}{l}0.000 \\
0.050 \\
0.105 \\
0.291 \\
0.479 \\
0.689 \\
0.919 \\
1.000\end{array}$ & $\begin{array}{l}0.6902 \\
0.6671 \\
0.6445 \\
0.5732 \\
0.5097 \\
0.4468 \\
0.3955 \\
0.3778\end{array}$ & $\begin{array}{l}42.85 \\
43.37 \\
43.96 \\
46.06 \\
48.27 \\
50.90 \\
53.53 \\
54.45\end{array}$ & $\begin{array}{l}3.065 \\
3.040 \pm 0.000 \\
3.006 \pm 0.002 \\
2.908 \pm 0.003 \\
2.898 \pm 0.004 \\
2.829 \pm 0.007 \\
2.561 \pm 0.011 \\
-\end{array}$ & $\begin{array}{l}- \\
2.228 \pm 0.010 \\
2.350 \pm 0.022 \\
2.320 \pm 0.007 \\
2.174 \pm 0.004 \\
2.155 \pm 0.003 \\
2.163 \pm 0.001 \\
2.132\end{array}$ \\
\hline 270 & $\begin{array}{l}0.000 \\
0.046 \\
0.098 \\
0.300 \\
0.488 \\
0.691 \\
0.901 \\
1.000\end{array}$ & $\begin{array}{l}0.9168 \\
0.8876 \\
0.8590 \\
0.7565 \\
0.6735 \\
0.5976 \\
0.5341 \\
0.5072\end{array}$ & $\begin{array}{l}43.47 \\
43.96 \\
44.54 \\
46.89 \\
49.19 \\
51.71 \\
54.30 \\
55.50\end{array}$ & $\begin{array}{l}4.130 \\
4.102 \pm 0.003 \\
4.063 \pm 0.004 \\
3.958 \pm 0.004 \\
3.856 \pm 0.009 \\
3.751 \pm 0.006 \\
3.536 \pm 0.027 \\
-\end{array}$ & $\begin{array}{l}- \\
2.878 \pm 0.060 \\
3.086 \pm 0.035 \\
3.023 \pm 0.010 \\
2.991 \pm 0.009 \\
2.959 \pm 0.002 \\
2.949 \pm 0.003 \\
2.917\end{array}$ \\
\hline 320 & $\begin{array}{l}0.000 \\
0.047 \\
0.096 \\
0.302 \\
0.496 \\
0.699 \\
0.888 \\
1.000\end{array}$ & $\begin{array}{l}1.1242 \\
1.0910 \\
1.0595 \\
0.9360 \\
0.8343 \\
0.7428 \\
0.6715 \\
0.6331\end{array}$ & $\begin{array}{l}44.11 \\
44.63 \\
45.19 \\
47.68 \\
50.14 \\
52.76 \\
55.19 \\
56.60\end{array}$ & $\begin{array}{l}5.139 \\
5.107 \pm 0.002 \\
5.088 \pm 0.007 \\
4.931 \pm 0.003 \\
4.826 \pm 0.007 \\
4.704 \pm 0.022 \\
4.165 \pm 0.014 \\
-\end{array}$ & $\begin{array}{l}3.858 \pm 0.051 \\
3.803 \pm 0.065 \\
3.925 \pm 0.008 \\
3.839 \pm 0.007 \\
3.787 \pm 0.003 \\
3.800 \pm 0.003 \\
3.713\end{array}$ \\
\hline 350 & $\begin{array}{l}0.000 \\
0.047 \\
0.092 \\
0.300 \\
0.475 \\
0.697 \\
0.888 \\
1.000\end{array}$ & $\begin{array}{l}1.2375 \\
1.2059 \\
1.1754 \\
1.0440 \\
0.9450 \\
0.8339 \\
0.7519 \\
0.7078\end{array}$ & $\begin{array}{l}44.50 \\
45.03 \\
45.56 \\
48.12 \\
50.38 \\
53.32 \\
55.83 \\
57.28\end{array}$ & $\begin{array}{l}5.707 \\
5.692 \pm 0.002 \\
5.673 \pm 0.005 \\
5.528 \pm 0.004 \\
5.413 \pm 0.011 \\
5.281 \pm 0.014 \\
4.800 \pm 0.026 \\
-\end{array}$ & $\begin{array}{l}- \\
4.350 \pm 0.042 \\
4.355 \pm 0.052 \\
4.463 \pm 0.009 \\
4.408 \pm 0.012 \\
4.318 \pm 0.006 \\
4.295 \pm 0.003 \\
4.201\end{array}$ \\
\hline
\end{tabular}

\section{Discussion}

It is usual to identify $M_{1}$ of a molten binary $\left(\mathrm{M}_{1}, \mathrm{M}_{2}\right) \mathrm{X}$ (salt mole fractions $x_{13}$ and $\left.x_{23}=1-x_{13}\right)$ with the metal which in the pure salt has a greater internal mobility than $\mathbf{M}_{2}$ in the pure salt $\left(b_{13}(0)\right.$ $\left.>b_{23}(1)\right)$. For $\mathrm{M}_{1}=\mathrm{Ag}, \mathrm{M}_{2}=\mathrm{Li}, \mathrm{Na}, \mathrm{K}, \mathrm{Rb}$ or $\mathrm{Cs}$, and $\mathrm{X}=\mathrm{NO}_{3}, b_{13}\left(x_{23}\right)$ was found to be greater than $b_{23}\left(x_{23}\right)$ in the studied range of concentrations and 

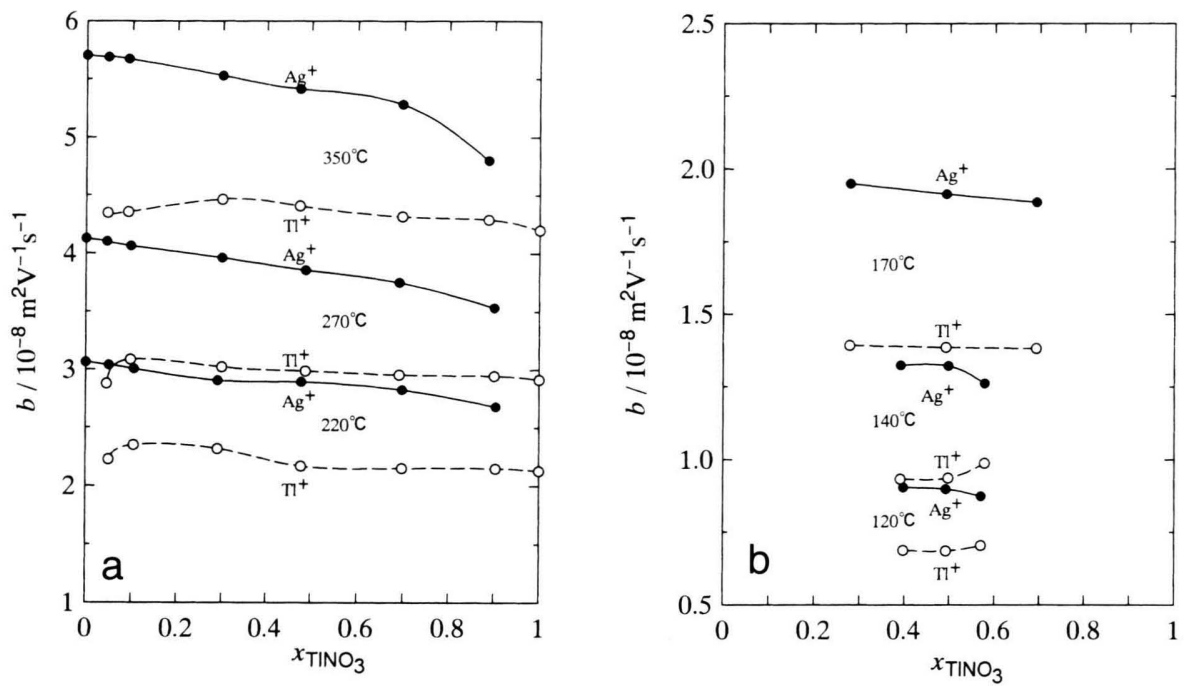

Fig. 1. Isotherms of $b_{\mathrm{Ag}}$ and $b_{\mathrm{Tl}}$. (a) $350^{\circ} \mathrm{C}, 270^{\circ} \mathrm{C}$, and $220^{\circ} \mathrm{C}$, (b) $170^{\circ} \mathrm{C}, 140^{\circ} \mathrm{C}$, and $120^{\circ} \mathrm{C}$.

temperatures. Figure 1 shows that this is also true for $\mathrm{M}_{1}=\mathrm{Ag}, \mathrm{M}_{2}=\mathrm{Tl}$ and $\mathrm{X}=\mathrm{NO}_{3}$.

Generally for such binaries, $b_{13}$ and $b_{23}$ decrease with increasing $x_{23}$, the decrease of $b_{13}$ being steeper than that of $b_{23}$. Figure 1 shows that for $(\mathrm{Ag}, \mathrm{Tl}) \mathrm{NO}_{3}$ this holds generally, but that it does not hold at $120^{\circ} \mathrm{C}$ and $140^{\circ} \mathrm{C}$ in the range $0.4<x_{23}<0.6$, and at $220^{\circ} \mathrm{C}$, $270^{\circ} \mathrm{C}$ and $350^{\circ} \mathrm{C}$ in the range $0<x_{23}<0.2$.

In [6] we will report on the mobilities in $(\mathrm{K}, \mathrm{Tl}) \mathrm{NO}_{3}$ and $(\mathrm{Cs}, \mathrm{Tl}) \mathrm{NO}_{3}$, so that then all systems listed in Table 1 will have been studied. On this occasion we intend to discuss the observations, including $(\mathrm{Ag}, \mathrm{Tl}) \mathrm{NO}_{3}$, in a broader context and in more detail.

[1] I. Okada and K. Ichioka, Z. Naturforsch. 47a, 781 (1992).

[2] K. Ichioka, I. Okada, and A. Klemm, Z. Naturforsch. 44 a, 747 (1989).

[3] P. Chou, H. Matsuura, I. Okada, and C. Yang, Z. Naturforsch. 48a, 1207 (1993).

[4] K. Kawamura, I. Okada, and O. Odawara, Z. Naturforsch. 30a, 69 (1975).

[5] S. Baluja, J. Habasaki, and I. Okada, Z. Naturforsch. 42 a, 377 (1987)

[6] P. Chou and I. Okada, to be published.

[7] G. J. Janz, C. B. Allen, J. R. Downey, and R. P. T. Tomkins, Physical Properties Data Compilations Relevant to Energy Storage. I. Molten Salts: Eutectic Data, U.S. Department of Commerce, 1978.

\section{Acknowledgements}

One of the authors (P. C.) wishes to thank the Rotary Club, Japan for the Yoneyama memorial scholarship.

The expenses of this work have been defrayed by the Grant-in-Aid for Scientific Research on Priority Areas (No. 07236103, Cooperative Phenomena in Complex Liquids) and (B) (No. 07454183) from the Ministry of Education, Science and Culture, Japan.

[8] I. Okada, R. Takagi, and K. Kawamura, Z. Naturforsch. 34a, 498 (1979).

[9] R. Takagi, K. Kawamura, and I. Okada, Z. Naturforsch. 39 a, 759 (1984).

[10] W. Herzog and A. Klemm, Z. Naturforsch. 13a, 7 (1958).

[11] V. Ljubimov and A. Lundén, Z. Naturforsch. 21 a, 1592 (1966).

[12] S. Brillant, Thesis, Strasbourg 1967. 